\title{
How Twitter may have helped Nigeria contain Ebola
}

Targeted social media campaigns in Nigeria helped to disseminate accurate information about the disease-and to correct hoax messages, Meg Carter reports

\author{
Meg Carter freelance journalist, Bath, UK
}

\begin{abstract}
"Social media is the fastest means of population feedback in the 21 st century and provides cheap two-way information [sharing]," says Lawal Bakare, the Nigerian dentist who created the Twitter campaign @EbolaAlert. And sharing information through links to its original form lends it credibility, he added. Bakare launched @EbolaAlert in July to recruit volunteers, disseminate accurate information, and facilitate discussion. Within a few weeks, he had 76000 followers, though on some days Bakare thinks that messages were shared among considerably more people. ${ }^{1}$

@EbolaAlert gives the public advice about prompt reporting and good environmental and personal hygiene. For example, "How to conduct safe \& dignified burial of a patient who died from suspected or confirmed Ebola (EVD)," with a link to guidance from the World Health Organization. Others tweets have targeted professionals, including announcing new WHO guidelines on personal protective equipment.
\end{abstract}

\section{Facebook and Unicef}

The campaign has spread to other platforms, including Facebook, and is helping in nearby countries. Other initiatives are also exploiting social media. In early November, Facebook confirmed plans to relay messages from Unicef in the region. It also introduced a button for users worldwide to donate to charities that are helping with the outbreak. ${ }^{2}$

Meanwhile, the BBC has a service in English and French on WhatsApp, the most used online chat application in west Africa, that provides text and audio information on Ebola such as identifying symptoms, how to reduce the risk of spreading the disease, and the need for effective handwashing.

To maximise reach WHO and the US Centers for Disease Control and Prevention (CDC) are providing information to Nigeria's health ministry, local healthcare organisations, popular bloggers, and others with large numbers of Facebook and Twitter connections.

Nigeria's population exceeds 174 million people, and it has more than 114 million mobile phone subscriptions. Almost 56 million Nigerians use the internet regularly, mostly through mobile devices, and interest in social media is growing fast. ${ }^{4}$
But penetration of this technology is only part of the story. Equally important is creating the "viral" messages that people will share.

In the US, the CDC distributes information on Ebola to the public and healthcare professionals using Facebook, Twitter, Instagram, Google+, and LinkedIn. Since August it has used Twitter to host six live question and answer sessions with experts and published the answers to the most commonly asked questions on other platforms.

The CDC has also used social media to provide people of west African descent living in America with advice for friends and relations in affected areas.

\section{Cholera in Haiti}

Social media may also help predict the epidemic's development. "The CDC and WHO now use a range of different kinds of data to produce a variety of models, from models built on case reports to others built on mobile data, social media data, and even airline data," says Marisa Eisenberg, a mathematical epidemiologist at the University of Michigan. She has studied several outbreaks of disease, including the cholera epidemic that followed the 2010 earthquake in Haiti, when mobile phone records were used to identify where people had fled. ${ }^{5}$

Such data may give clues about how people's behaviour changes during outbreaks of disease. Several organisations are analysing current mobile phone data. In Senegal, anonymised data from 150000 handsets were sent to the Swedish non-profit Flowminder to map population movements in the region. Authorities have used this to inform the location of treatment centres. The CDC collects additional data to map where calls to Ebola helplines come from. ${ }^{6}$

Social media can also present challenges for those dealing with outbreaks, however. One hoax meme, for example, urged Nigerians to drink excessive amounts of salt water. It may have led to two deaths and more than 12 admissions to hospital, news reports suggested.

"It's not enough to broadcast a message then sit back and wait for it to spread," says Ed Kitchingham, research and insight 
director at the communications agency We Are Social. You then need to "monitor conversation around the subject, respond as and when needed, help the conversation move in the right direction, and be aware of any false messaging and quash it, quickly," he said.

"Anyone can offer Ebola 'advice,"” added Sari Setiogi, the Ebola social media lead at WHO's department of communications. "This is why it is extremely important to build relationships and trust on social media before a crisis hits."

Constant monitoring is the best way to combat misinformation, thinks Carol Crawford, chief of the digital media branch of the CDC's public affairs division. It "helps us refine our messages and identify where more work is needed," she explained.

"It's how we now know the importance of displaying information in a variety of different formats-for example, infographics have proven especially effective. And it's why we're now so clear on the importance of having an open, two-way conversation."

Nigeria had 20 cases of Ebola and eight deaths, and the outbreak was declared over on 17 October. ${ }^{8}$ Sierra Leone has had at least 4862 cases and 1130 deaths, government figures show. ${ }^{9}$ Industry estimates suggest that although $57 \%$ of Sierra Leone's population own a mobile phone just $2 \%$ of the population have access to the internet. ${ }^{10}$
Competing interests: I have read and understood BMJ policy on declaration of interests and have no relevant interests to declare. Provenance and peer review: Commissioned; not externally peer reviewed.

1 Wallis W. Nigerian Twitter campaign informs the world about Ebola. Financial Times 2014 Oct 19. www.ft.com/cms/s/0/924a21d4-55e7-11e4-93b3-00144feab7de.html\# axzz3IOUPzv36.

2 Gleit N, Daniels C. Coming together to fight Ebola, 6 November 2014. http://newsroom. fb.com/news/2014/11/coming-together-to-fight-ebola/.

3 BBC launches WhatsApp Ebola service, BBC News 2014 Oct 16. www.bbc.co.uk/news/ world-africa-29573964.

4 African digital statistics. Social Media Week 2014 Feb 3. http://socialmediaweek.org/ lagos/2014/02/03/african-digital-statistics-2014/.

5 Why mobile data to prevent Ebola has not yet been released. Economist 2014 Nov 9. www.economist.com/blogs/economist-explains/2014/11/economist-explains-4?fsrc=nlw\% 7Cnewe\%7C10-11-2014\%7C.

6 Wall M. Ebola: Can big data analytics help contain its spread? BBC News 2014 Oct 15 www.bbc.co.uk/news/business-29617831.

7 Neporent L. Nigerian Ebola hoax results in two deaths. ABC News $2014 \mathrm{http}: / / a b c n e w s$. go.com/Health/nigerian-ebola-hoax-results-deaths/story?id=25842191.

8 WHO. Ebola response roadmap situation report update, 7 November 2014. http://apps. who.int/iris/bitstream/10665/137592/1/roadmapsitrep_7Nov2014_eng.pdf?ua=1.

9 O'Carroll L. Ebola cases in Sierra Leone show sharp rise. Guardian 2014 Nov 10. www. theguardian.com/world/2014/nov/10/ebola-cases-sierra-leone-sharp-rise.

10 Sierra Leone-telecoms, mobile and broadband. Market insights and statistics www. budde.com.au/Research/Sierra-Leone-Telecoms-Mobile-and-Broadband-Market-Insightsand-Statistics.html.

Cite this as: BMJ 2014;349:96946

๑) BMJ Publishing Group Ltd 2014 